\title{
Bentonites from Boa Vista, Brazil: Physical, Mineralogical and Rheological Properties
}

\author{
Luciana Viana Amorim ${ }^{\mathrm{a} *}$, Cynthia Morais Gomes ${ }^{\mathrm{a}}$, Helio de Lucena Lira ${ }^{\mathrm{a}}$, \\ Kepler Borges França ${ }^{\mathrm{b}}$, Heber Carlos Ferreira ${ }^{\mathrm{a}}$ \\ ${ }^{a}$ Departamento de Engenharia de Materiais, Universidade Federal de Campina Grande \\ ${ }^{\mathrm{b}}$ Departamento de Engenharia Química, Universidade Federal de Campina Grande \\ Av. Aprígio Veloso, 882, 58109-970, Campina Grande, Paraíba, Brazil
}

Received: May 3, 2004; Revised: September 16, 2004

\begin{abstract}
The aim of this work is to characterize physically and mineralogically six samples of natural and industrialized bentonites from Paraíba, Brazil, and to study its rheological properties to be used as a components of water based drilling fluids. Also it is intended to compare the evolution of the mineralogical composition and rheology of these clays after 40 years of exploitation. The natural bentonite clays were transformed into sodium bentonite by addition of concentrated $\mathrm{Na}_{2} \mathrm{CO}_{3}$ solution. The suspensions were prepared with $4.86 \% \mathrm{w} / \mathrm{w}$ to measure their rheological properties (apparent and plastic viscosities and water loss). The results showed that: i) the samples present typical mineralogical compositions of bentonites, but after four decades of exploitation, presents inferior quality and ii) among the clays samples, only one presented satisfactory rheological properties be used as a components of water based drilling fluids.
\end{abstract}

Keyword: Bentonite, mineralogical characterization, rheology, drilling fluids

\section{Introduction}

The name bentonite was suggested initially to the plastic clays found in Fort Benton, Wyoming, USA. These clays present the property of increasing several times its initial volume in the presence of humidity. They are composed, predominantly, of smectite clay minerals, and it is usually sodium and calcium montmorillonites ${ }^{1}$.

The bentonites are included in the class of the minerals with larger industrial interest. According to $\mathrm{Murray}^{2}$, the several industrial applications of these clays are due to its physical and chemical properties (such as, high surface area and cation exchange capacity). They are traditionally applied in oil well drilling mud, as a bonding agent for foundry molding sands, pelletizing iron ores, sealants, animal feed bonds, bleaching clay, agricultural carriers, pet litter adsorbents, adhesives, pharmaceuticals, emulsion stabilizers, desiccants, catalysts, cosmetics and paint, and, recently, it has been used in nanocomposites. The importance of these practical applications is related to rheological properties ${ }^{3}$. Sodium montmorillonite clay is particularly of interest due to its high swelling capacity and formation of a gel-like structure at relatively low clay concentrations ${ }^{4}$.

Research performed in the early 90's by the Bureau of Mines of the U.S.A, showed that the sum of bentonite de-

*e-mail: luciana@labdes.ufcg.edu.br posits in the world is about 1.36 billion tons, and the U.S.A. has more than $50.0 \%$ of the total ${ }^{5}$. In Brazil, the bentonites can be found in relatively small deposits. The most important one is located in the northeast of Brazil, Paraíba State, in the city of Boa Vista (Fig. 1). These clays were discovered in the beginning of the 60's and the first studies showed that these clays were naturally polycationic and could be transformed into sodium bentonites with rheological properties in accordance with the specifications of American Petroleum Institute - API. It was verified that these clays were composed of the clay minerals montmorillonite, illite, kaolinite and mixed layers of illite-montmorillonite and quartz. Also it was established that when these clays are treated with a concentrated sodium carbonate solution it is possible to obtain sodium bentonites capable to substitute the natural sodium bentonites imported by Brazil ${ }^{6}$. An extensive study related with the treatment of these clays with sodium carbonate was done, and resulted in 18 different processes ${ }^{7}$.

In the 70's and 80's decades research was carried out in the Federal University of the Paraíba-UFPB ${ }^{8-14}$ and in the University of São Paulo-USP ${ }^{15,16}$ with the objective to develop techniques of ionic exchange treatment to improve the rheological properties of these clays. 
The origin of the clays from Boa Vista-PB was studied by Gopinath et al. ${ }^{17}$ and showed that these clays are alterations of glassy material, derived from volcanic ash. Years later, in 1988, the same authors showed that these clays are composed of montmorillonite, illite, kaolinite, quartz and feldspar and can be labeled bentonite ${ }^{18}$.

With the discovery of these bentonites Brazil gradually started to produce bentonites in the sodium and calcium forms, supplying the demands of the internal market. According to the National Department of Mineral Production - DNPM, the amount of natural and treated (sodium bentonite) clays produced in the Paraíba State represents 96.0\% of the national production and $74.0 \%$ of this amount is produced in Campina Grande City, Paraiba State and $4.0 \%$ is produced in the São Paulo State ${ }^{5}$.

The drilling fluids, also called muds, are used in the oil wells drilling process to remove cuttings, to keep formation fluids confined to their formations, to lubricate the bit, and to build an impervious coating on the wall of the hole in order to impede the penetration of water from the drilling fluid into the formation ${ }^{1}$. According to Caenn and Chillingar ${ }^{19}$, the water based drilling fluids are used all over the world, in most of the perforations. Petrobras, the Brazilian Petroleum Company, uses water based drilling fluids with bentonite clay in onshore and offshore perforations. Almost all of this clay comes from Boa Vista City, Paraíba State.

Nowadays, after 40 years of exploitation some different type of clays from Boa Vista, PB become exhausted and others become rare, such as Chocolate clay having good properties. On the other hand there are some clays found in great amount such as Bofe e Verde-lodo but with inferior quality.

The objectives of this work are: i) to characterize physically and mineralogically three samples of natural bentonites from Boa Vista City, Brazil and three industrialized samples; ii) to study the rheological properties of these clays to be used as thixotropic agents for water based drilling fluids and iii) to carry out a comparative study of the evolution of the mineralogical composition and rheology of these clays after 40 years of exploitation.
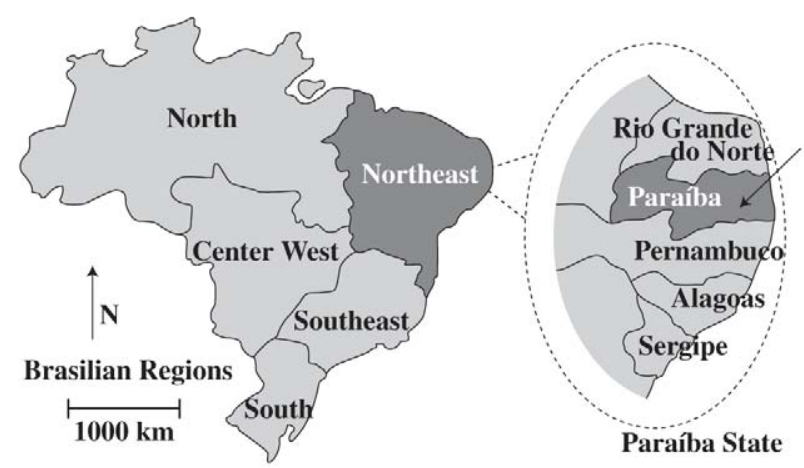

Figure 1. Location of the studied area.

\section{Materials and Methods}

\subsection{Bentonites}

Three samples of natural bentonites were studied, from Boa Vista City, Paraíba State, Brazil, namely locally as Bofe, Chocolate and Verde-lodo. Three samples of industrialized bentonites in the sodium form, supplied by local industries and identified as Dolomil, Brasgel and Brasgel PA, were also studied. The natural clays were dried at $60 \pm 2{ }^{\circ} \mathrm{C}$ for a period of 7 days, milled and screened in a ASTM 200 (aperture size of $0.074 \mathrm{~mm}$ ) sieve.

\subsection{Physical and mineralogical characterization}

The water content and the particle size were evaluated according to the Brazilian norm $\mathrm{N}-2605^{20}$. The cation exchange capacity (CEC) and the surface area were determined by the method of methylene blue adsorption ${ }^{21}$.

The chemical composition of the clays was analyzed according to the methods developed by the Laboratory of Mineral Analyses (LAM), Center of Sciences and Technology (CCT), Federal University of Campina Grande (UFCG), Brazil $^{22}$.

Differential thermal analysis (DTA) and thermogravimetric analysis (TGA) were obtained with a BP Engenharia equipment, model BP 3000 , operating at a rate of $12.5^{\circ} \mathrm{C} / \mathrm{min}$ and maximum temperature of $1000{ }^{\circ} \mathrm{C}$. For DTA calcined aluminum oxide $\left(\mathrm{Al}_{2} \mathrm{O}_{3}\right)$ was used as a reference powder.

The X-ray diffraction pattern of the natural and industrialized samples and treated with ethylene glycol were obtained with a Diffractometer Siemens/Brucker, model AXS D5005, with $\mathrm{CuK} \alpha$ radiation $(\lambda=1.54056 \AA)$.

Infrared spectrums were obtained with a Nicolet Avatan equipment, model 360 , operating in the range of 4000 $400 \mathrm{~cm}^{-1}$. The sample powders were tested in the form of a disc by pressing using potassium bromide $(\mathrm{KBr})$.

Transmission electron micrographs were obtained with a TEM Philips CM 200 equipment, operating at $200 \mathrm{kV}$.

\subsection{Transformation of natural bentonites into sodium bentonites}

The natural clays were treated with $\mathrm{Na}_{2} \mathrm{CO}_{3}$ concentrated solution (200 g/L) in proportions of: $75,100,125,150$ and $175 \mathrm{meq} / 100 \mathrm{~g}$ of dry clay for the sample Bofe, and 50, 75, 100,125 and $150 \mathrm{meq} / 100 \mathrm{~g}$ of dry clay for the sample Chocolate and Verde-lodo. After, the samples were cured for a period of 5 days in humid chamber, according to the process developed by Zandonadi et al. ${ }^{7}$.

\subsection{Preparation of suspensions}

The suspensions of the natural clays treated with a $\mathrm{Na}_{2} \mathrm{CO}_{3}$ solution and the industrialized clays in a concentration of $4.86 \% \mathrm{w} / \mathrm{w}$ were prepared according to the 
Petrobras standards N-2605 ${ }^{20}$. After, the suspensions remain for a period of $24 \mathrm{~h}$ in a humid chamber, at $100 \%$ of relative humidity.

\subsection{Determination of the rheological properties}

The rheological properties of the suspensions were carried out according to the Petrobras standards N-2605 ${ }^{20}$. The apparent viscosity (AV) and plastic viscosity (PV), were measured by using a Fann viscosimeter, model 35A, and the water-loss (WL) through a filter paper, was determined by using a filter press Fann model. The $\mathrm{pH}$ was evaluated by using a digital $\mathrm{pH}$ meter, Analyser model.

Table 1. Water content and particle size for the natural and industrialized bentonites.

\begin{tabular}{ccc}
\hline Samples & $\begin{array}{c}\text { Water content } \\
(\%)\end{array}$ & $\begin{array}{c}\text { Particle size } \\
+200 \mathrm{Mesh} \\
(0.074 \mathrm{~mm})(\%)\end{array}$ \\
\hline Bofe & 2.77 & 0.02 \\
Chocolate & 4.31 & 0.44 \\
Verde-lodo & 2.45 & 0.06 \\
Dolomil & 3.79 & 2.00 \\
Brasgel & 2.88 & 0.10 \\
Brasgel PA & 5.28 & 1.26 \\
Maximum value* & 14.0 & 4.0 \\
\hline
\end{tabular}

* According to the Petrobras specification ${ }^{23}$.

Table 2. Cation exchange capacity (CEC) and surface area determined by the method of methylene blue adsorption.

\begin{tabular}{ccc}
\hline Samples & $\begin{array}{c}\text { CEC } \\
\text { (meq/100 g of dry clay) }\end{array}$ & $\begin{array}{c}\text { Surface area } \\
\left(\mathrm{m}^{2} / \mathrm{g}\right)\end{array}$ \\
\hline Bofe & 76 & 593 \\
Chocolate & 92 & 717 \\
Verde-lodo & 68 & 530 \\
Dolomil & 100 & 780 \\
Brasgel & 104 & 811 \\
Brasgel PA & 104 & 811 \\
\hline
\end{tabular}

\section{Results and Analysis}

\subsection{Physical and mineralogical characterization}

\subsubsection{Water content and particle size}

According to the Petrobras specification $\mathrm{N}-2604^{23}$, the water content of the natural and activated clays should not exceed the maximum of $14.0 \%$. Through the data contained in the Table 1, it is observed that all the samples presented water contents below the maximum, with exception of the samples Chocolate and Brasgel PA.

In relation to the particle size, the samples Bofe and Verdelodo contained the smallest amount of coarser grains $(>74 \mu \mathrm{m})$. According to the Petrobras standards N-260423, all samples contained particle sizes below the specification $(<4.0 \%)$.

\subsubsection{Cation exchange capacity and surface area}

The values of the cation exchange capacity ranged from $76 \mathrm{meq} / 100 \mathrm{~g}$ of clay for the sample Bofe, to $104 \mathrm{meq} / 100 \mathrm{~g}$ of clay for the samples Brasgel and Brasgel PA. The surface area ranged from $593 \mathrm{~m}^{2} / \mathrm{g}$ for the sample Bofe to $811 \mathrm{~m}^{2} / \mathrm{g}$ for the samples Brasgel and Brasgel PA (Table 2); these values are typical for bentonites ${ }^{24}$. The industrialized samples presented larger values of CEC and specific area; this behavior is due to the fact that these clays are in the sodic form and are easily dispersed.

\subsubsection{Chemical analysis}

The loss on ignition (LI) represents the loss of inserted water, water from hydroxyl groups on the clay minerals, organic matter and carbonates ${ }^{24}$. The loss on ignition ranged from $8.59 \%$, for the sample Brasgel PA, to $20.47 \%$, for the sample Chocolate (Table 3). $\mathrm{Fe}_{2} \mathrm{O}_{3}$ ranged from $6.83 \%$, for the sample Bofe, to $8.78 \%$, for the sample Verde-lodo (Table 3). The amounts of $\mathrm{Fe}_{2} \mathrm{O}_{3}$, are derived from the crystalline lattice of illite, that contains about $4 \%$ to $6 \%$ of $\mathrm{Fe}_{2} \mathrm{O}_{3}$, and from the clay minerals of the smectite group, that is, montmorillonite or members from the series nontronitebeidellite, according to Souza Santos ${ }^{24}$.

Table 3. Chemical composition of the natural and industrialized bentonites.

\begin{tabular}{cccccccccc}
\hline Samples & & \multicolumn{7}{c}{ Chemical analyses (\%) } & \\
& $\mathrm{LI}^{*}$ & $\mathrm{IR}^{* *}$ & $\mathrm{SiO}_{2}$ & $\mathrm{Fe}_{2} \mathrm{O}_{3}$ & $\mathrm{Al}_{2} \mathrm{O}_{3}$ & $\mathrm{CaO}$ & $\mathrm{MgO}$ & $\mathrm{Na}_{2} \mathrm{O}$ & $\mathrm{K}_{2} \mathrm{O}$ \\
\hline Bofe & 18.42 & 1.79 & 54.97 & 6.83 & 16.82 & Trace & Trace & 0.38 & 0.15 \\
Chocolate & 20.47 & 2.74 & 46.10 & 7.66 & 21.09 & Trace & Trace & 1.68 & 0.22 \\
Verde-lodo & 15.43 & 2.20 & 45.68 & 8.78 & 23.65 & Trace & Trace & 1.82 & 1.99 \\
Dolomil & 20.42 & 2.51 & 45.93 & 7.54 & 20.10 & Trace & Trace & 2.84 & 0.34 \\
Brasgel & 18.37 & 2.14 & 51.69 & 7.19 & 18.76 & Trace & Trace & 1.50 & 0.23 \\
Brasgel PA & 8.59 & 1.49 & 55.46 & 7.88 & 22.00 & Trace & 3.00 & 1.00 & 0.50 \\
Media*** & 16.30 & $\mathrm{ND}$ & 51.10 & 6.78 & 17.30 & 0.52 & 3.46 & 0.58 & 0.55 \\
\hline
\end{tabular}

${ }^{*} \mathrm{LI}$ - loss ignition at $1000{ }^{\circ} \mathrm{C},{ }^{* *} \mathrm{IR}$ - insoluble residue, ***Sample studied by Souza Santos ${ }^{6}$ when the deposit was discovered in Boa Vista, $\mathrm{PB}$ and ND - not determined. 
All samples included traces of calcium oxide $(\mathrm{CaO})$ and magnesium oxide $(\mathrm{MgO})$. The $\mathrm{MgO}$ content of Brasgel PA, was $3.00 \%$. The sample Verde-lodo contained $1.99 \%$ of $\mathrm{K}_{2} \mathrm{O}$, which is more than the other samples.

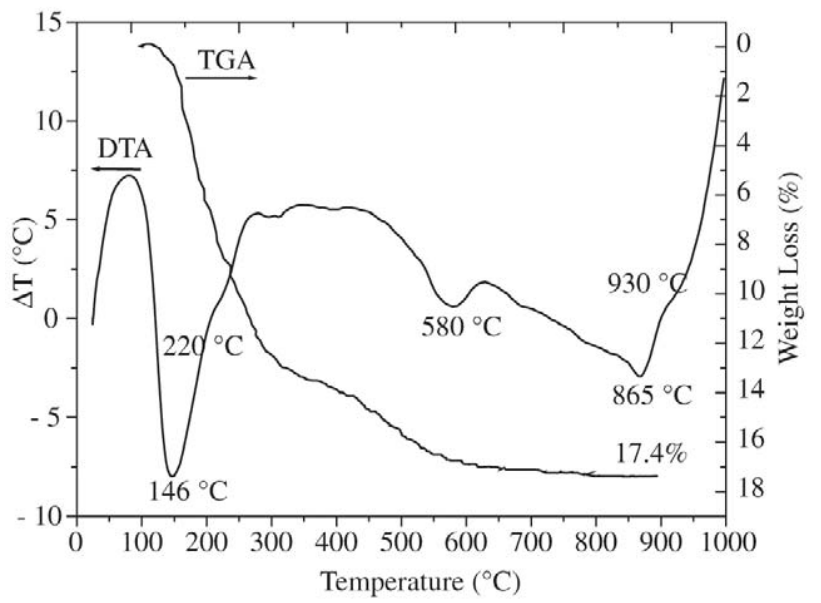

(a)

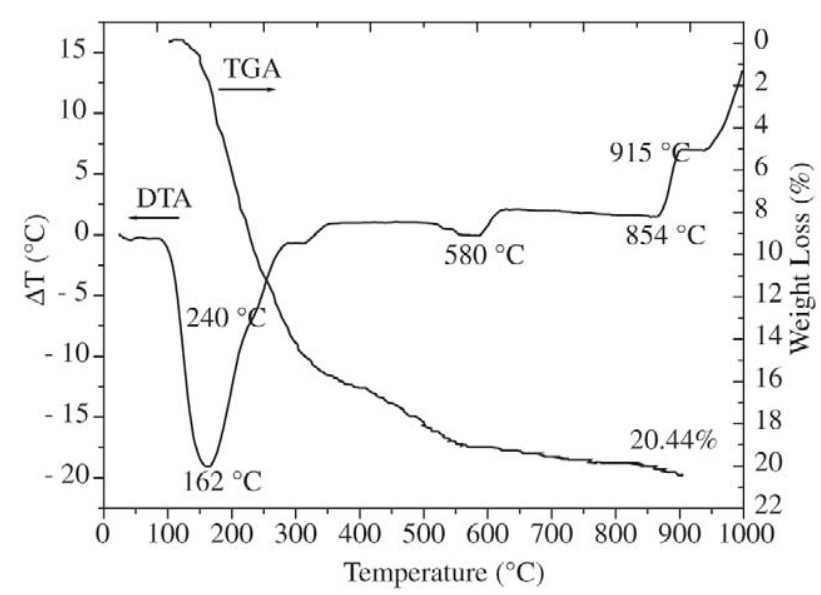

(b)

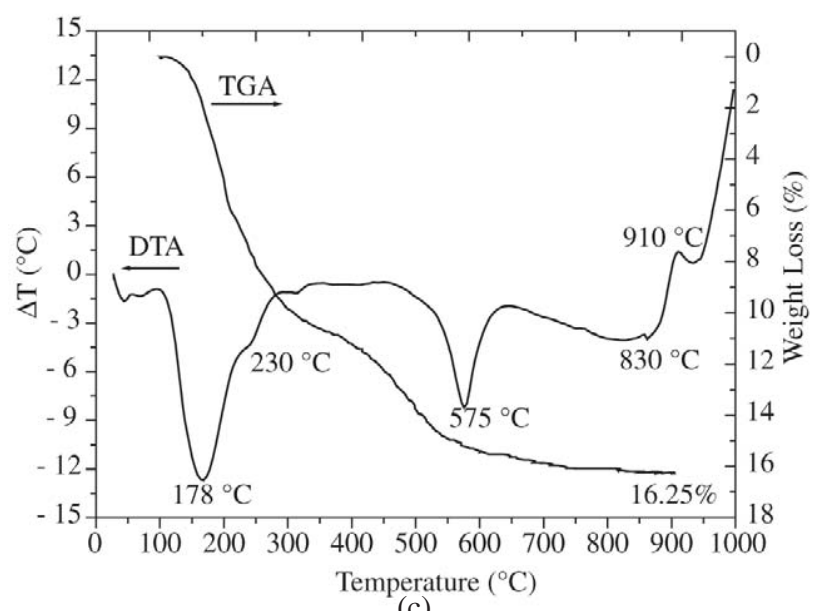

\subsubsection{Thermal analysis}

The differential thermal analysis and thermogravimetric curves of the clays are presented in Fig. 2. They are similar and typical for bentonites. The differential thermal curves

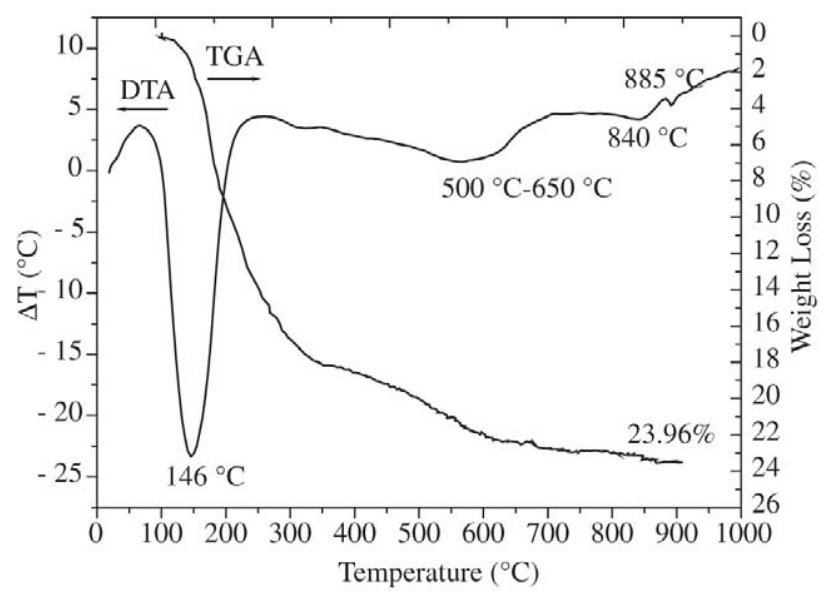

(d)

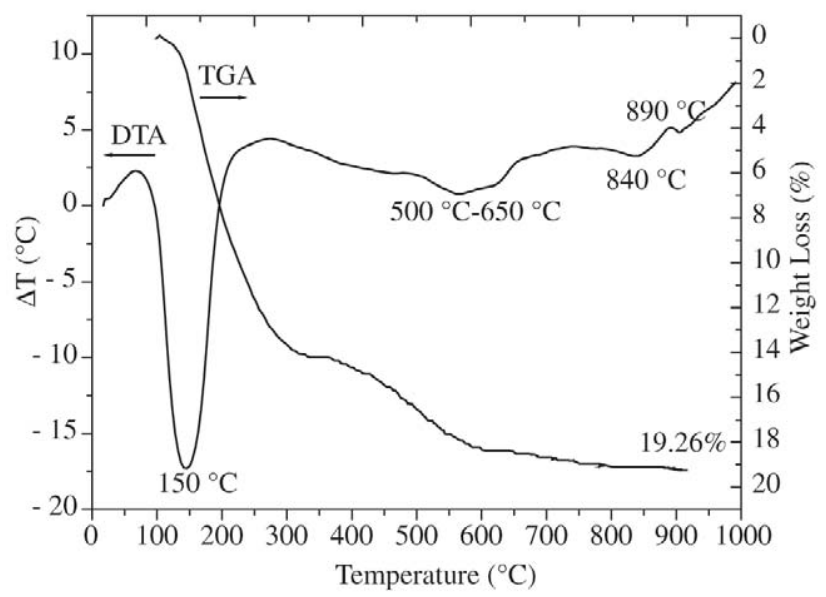

(e)

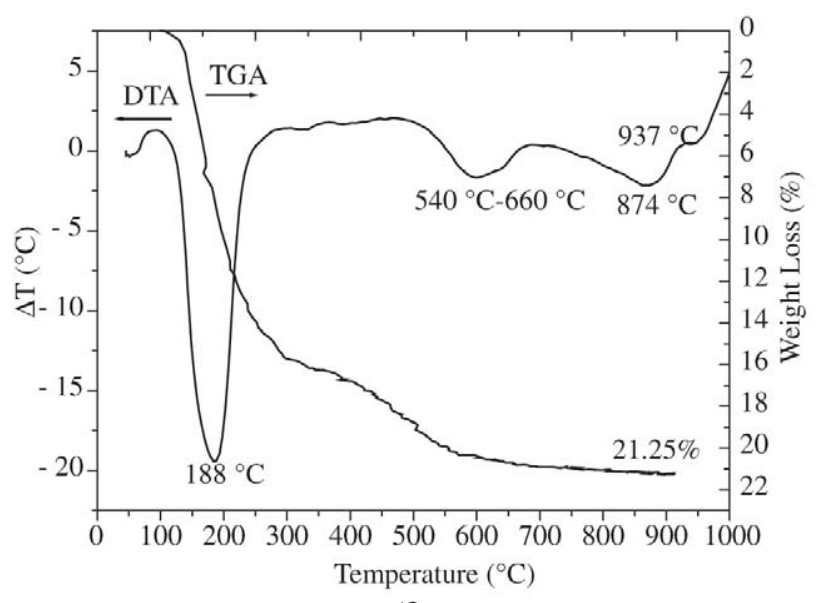

(f)

Figure 2. Differential thermal analysis and thermogravimetric curves for the bentonites: a) Bofe; b) Chocolate; c) Verde-lodo; d) Dolomil; e) Brasgel; f) Brasgel PA. 
present endothermic peaks characteristic of adsorbed water and hydroxyl groups from the clay mineral structure. Also the curve presents endo-exothermic peaks characteristic from formation of $\alpha$ or $\beta$-quartz of mullite. The thermogravimetric curve presented a slope related to the loss of hygroscopic water and hydroxyl groups.

The samples Bofe, Chocolate and Verde-lodo present undulations at approximately $220^{\circ} \mathrm{C}, 240^{\circ} \mathrm{C}$ and $230^{\circ} \mathrm{C}$, respectively. These are due to the presence of water coordinated to calcium and magnesium. This confirms the nature of polycationic clays. It was also observed that all the samples presented an endothermic band between $500^{\circ} \mathrm{C}$ and $650{ }^{\circ} \mathrm{C}$, characteristic of the hydroxyl loss of bentonite rich in iron.
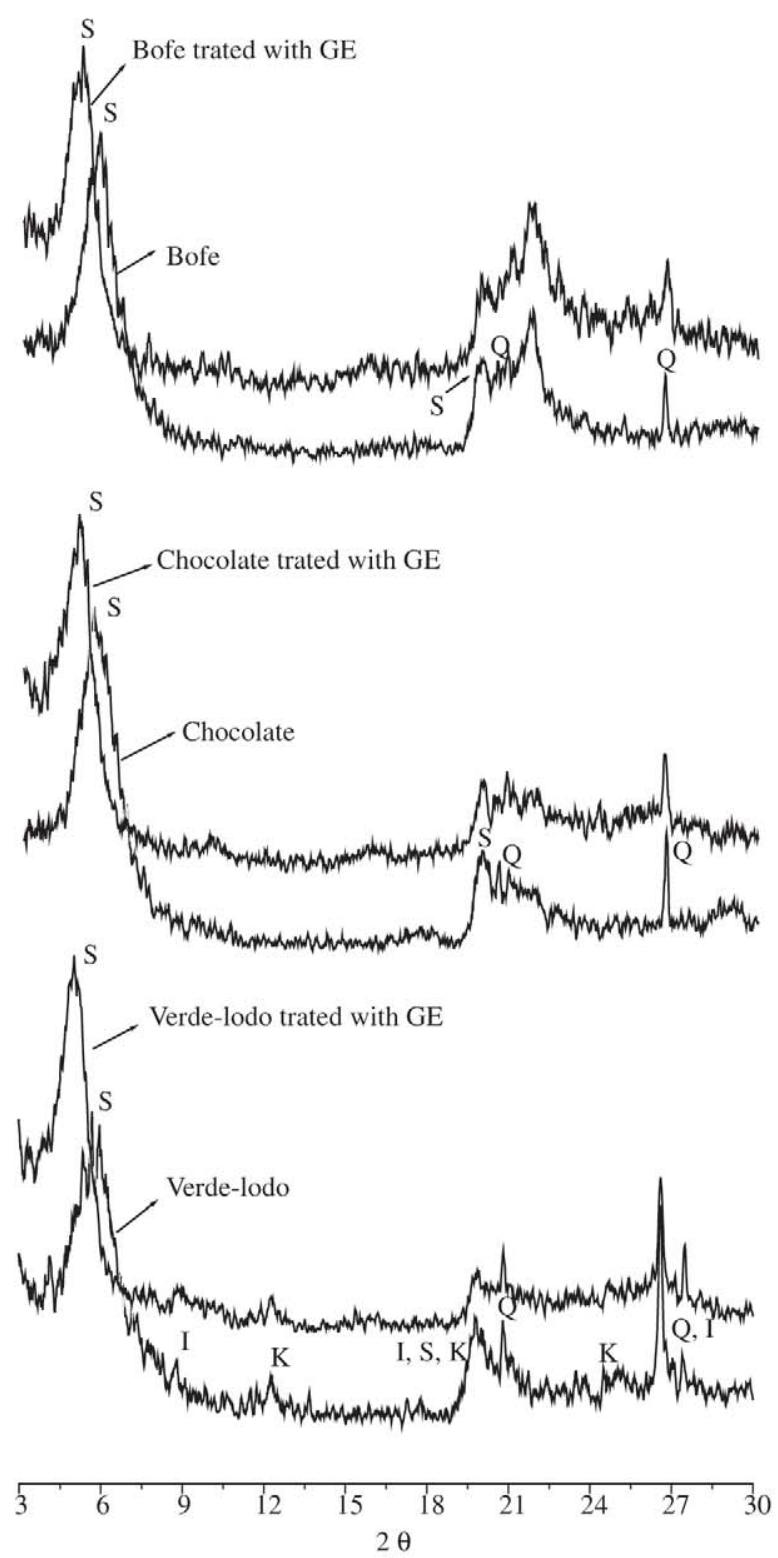

\subsubsection{X-ray diffraction}

The X-ray diffraction pattern of the samples (Fig. 3) presents typical diffractograms of bentonite, with a presence of clay minerals from the smectite group. These are confirmed by the change of its characteristic peak, after treatment with ethylene glycol, from $14-15 \AA$ to $17 \AA$. All the samples presented a peak at $3.35 \AA$, characteristic of the presence of the quartz. For the sample Verde-lodo (Fig. 3) a peak at 7.19 ̊ was observed, characteristic of kaolinite and a band between $4.55 \AA$ and $4.35 \AA$, with superposition of peaks, characteristic of kaolinite, illite and clay minerals from the smectite group, probably montmorillonite or member from the nontronite-beidellite series.
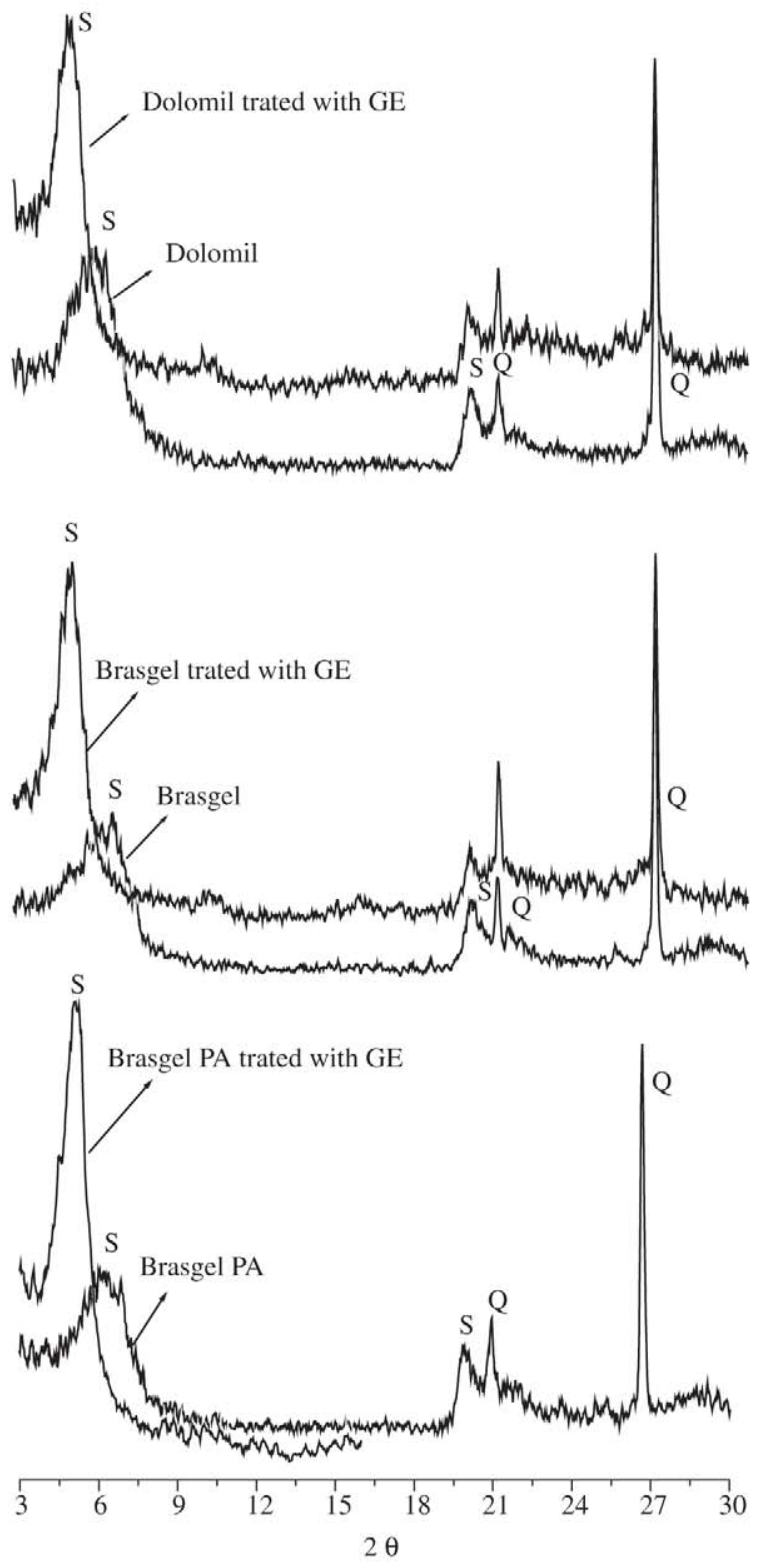

Figure 3. X-ray diffractions patterns for the bentonite samples: a) Bofe; b) Chocolate; c) Verde-lodo; d) Dolomil; e) Brasgel; f) Brasgel PA. 


\subsubsection{Infrared spectroscopy}

The infrared spectrums of the clay samples are presented in Fig. 4. The spectra of the samples are quite similar, with $\mathrm{Si}-\mathrm{O}-\mathrm{Si}$ stretching vibration band that manifests at $1039.8 \mathrm{~cm}^{-1}, \mathrm{O}-\mathrm{H}$ stretching bands situated at $3626.25 \mathrm{~cm}^{-1}$ and $3425.08 \mathrm{~cm}^{-1}$ and a stretching and bending vibration of hydration water that are manifested at $1635 \mathrm{~cm}^{-1}$. The set of the weak bands, which occurred in the range $920-550 \mathrm{~cm}^{-1}$
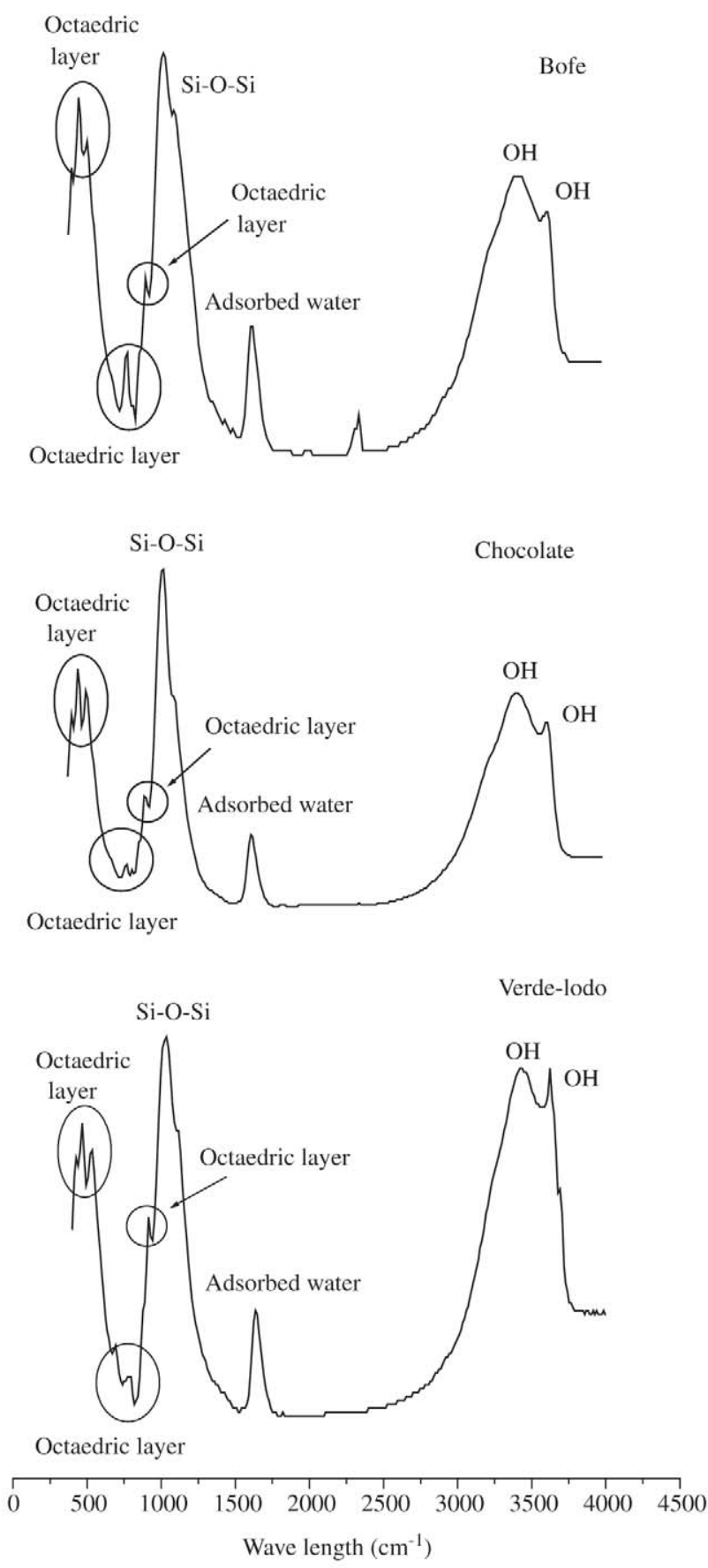

is ascribed to R-OH vibrations. According to Mendioroz et $a l^{25}$, the octahedral layers occurred at 920,800 and $525 \mathrm{~cm}^{-1}$. According to Srasra et al. ${ }^{26}$, the tetrahedral bending modes of Al-O-Si, Si-O, Si-O-Mg and Si-O-Si of the clay minerals occurred at 545, 472 and $429 \mathrm{~cm}^{-1}$, respectively.

\subsubsection{Transmission electron microscopy}

The micrographs of the samples (Fig. 5) presented typi-

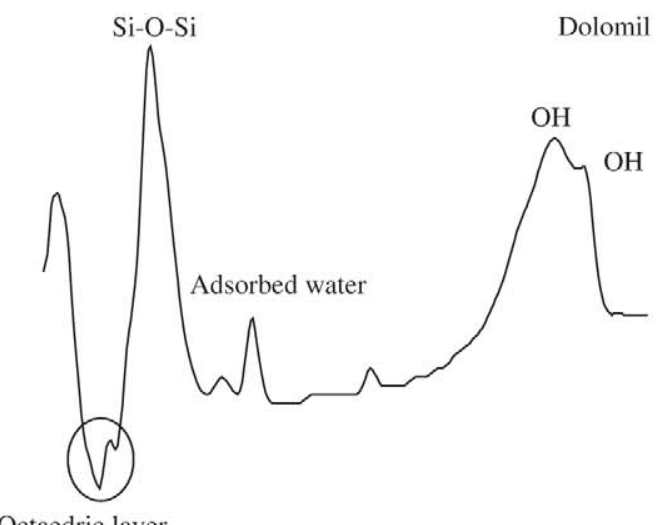

Octaedric layer
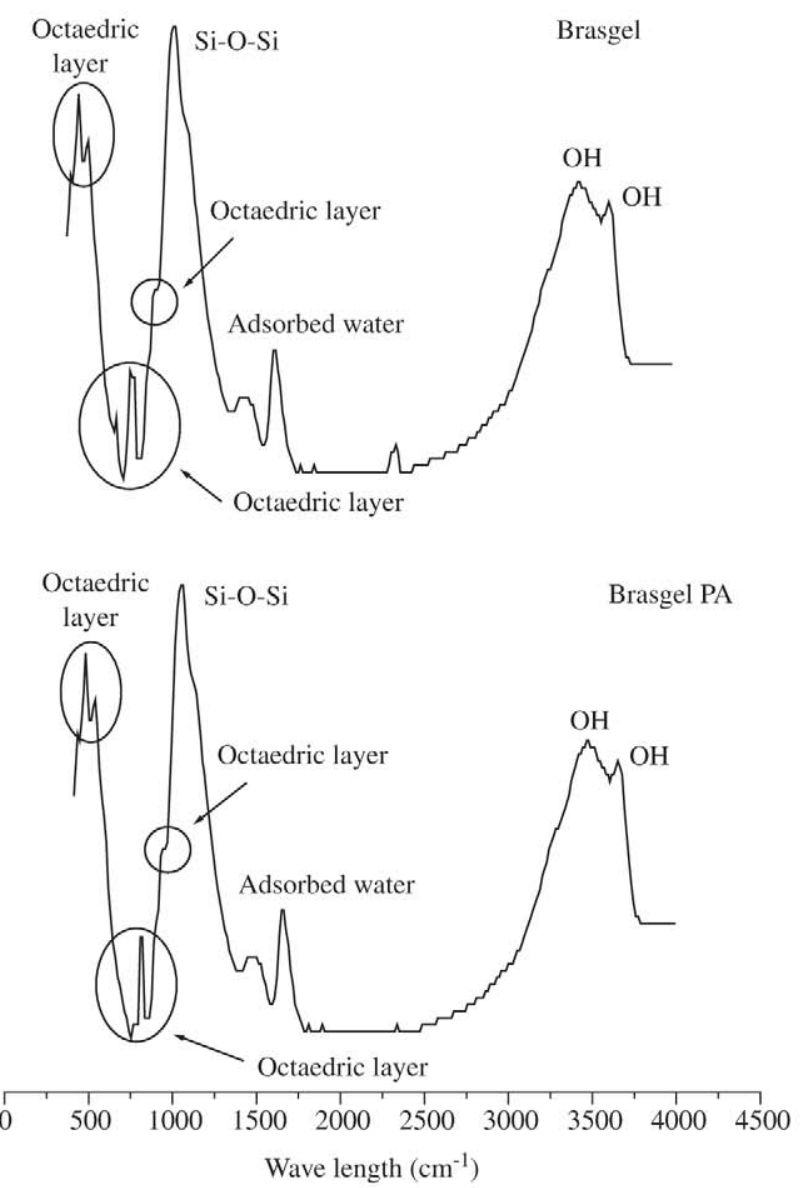

Figure 4. Infrared spectrums for the bentonite samples: a) Bofe; b) Chocolate; c) Verde-lodo; d) Dolomil; e) Brasgel; f) Brasgel PA. 

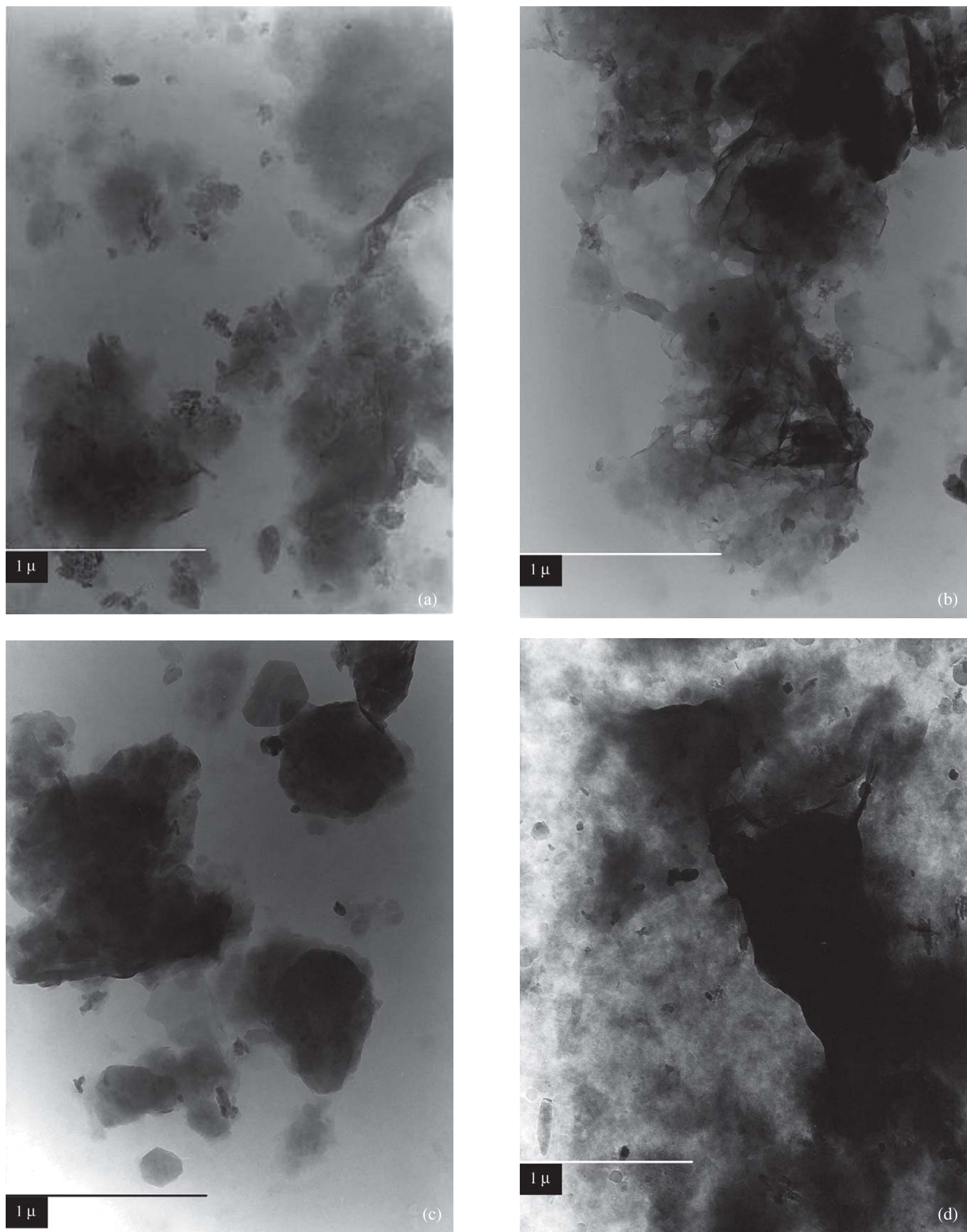

Figure 5. Micrographs of the bentonite samples: a) Bofe; b) Chocolate; c) Verde-lodo; d) Dolomil; e) Brasgel; f) Brasgel PA. Continue next page. 

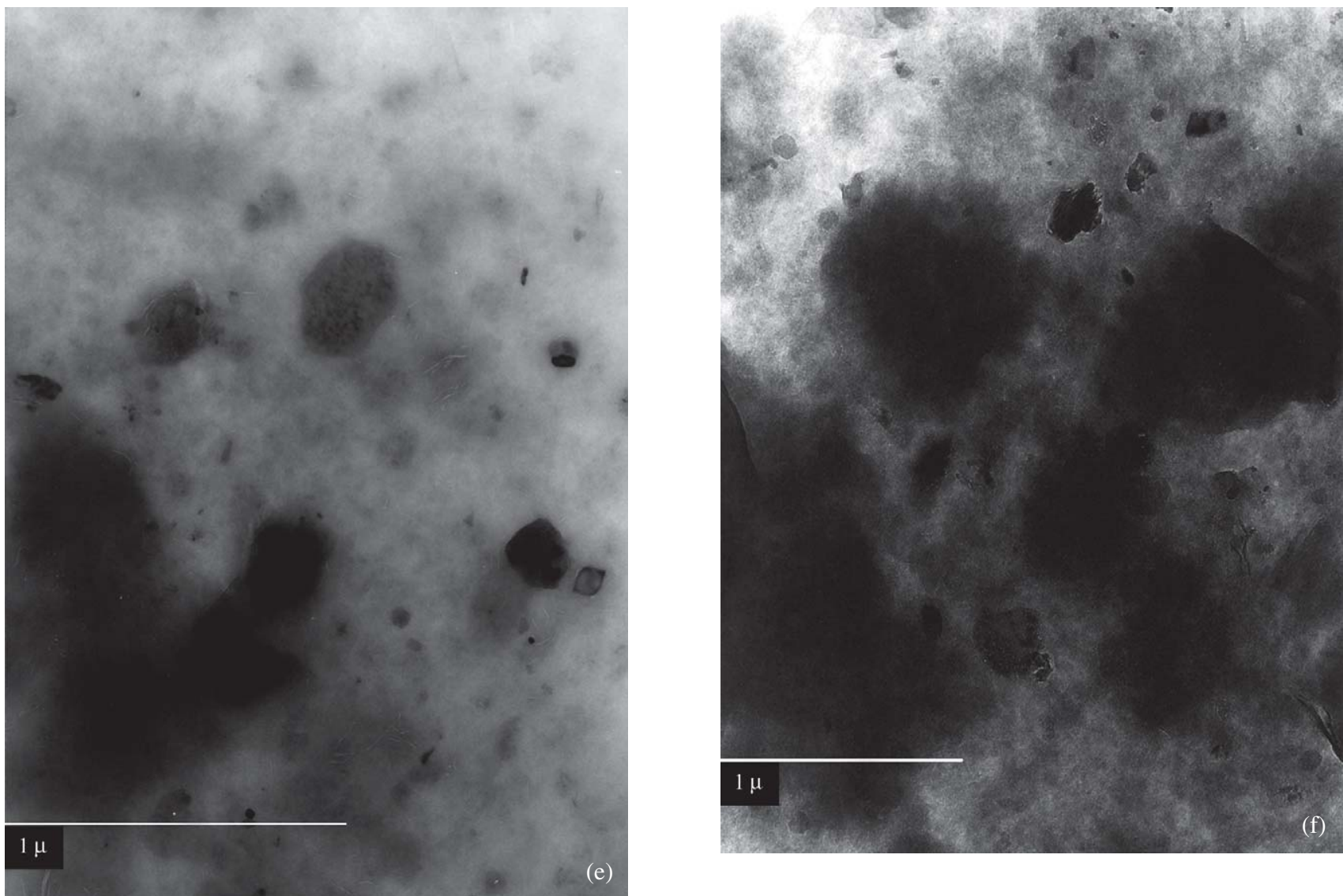

Figure 5. Micrographs of the bentonite samples: a) Bofe; b) Chocolate; c) Verde-lodo; d) Dolomil; e) Brasgel; f) Brasgel PA.

cal aspects of clay minerals from the smectite group, with irregular profile particles, undefined shape and great tendency to present curled edges, probably due to small plate diameter. Also, some irregular flake-shaped aggregates can be seen due to the attraction between the particles. In the micrograph (Fig. 5c) for sample Verde-lodo particles with hexagonal profile and lath-shapes can be observed, indicating the presence of kaolinite and illite, respectively, confirmed by X-ray results.

\subsection{Rheological behavior}

The rheological properties of the bentonite suspensions are given in Table 4. The increase in the proportion of $\mathrm{Na}_{2} \mathrm{CO}_{3}$ provide to the dispersions prepared with the natural clays an increase on apparent viscosity (AV) and decrease on plastic viscosity (PV) and water loss (WL), except for the sample Bofe, where PV did not present significant variations. This behavior shows the capacity of the natural clays to transform to the sodic form. The amount of $\mathrm{Na}_{2} \mathrm{CO}_{3}$ that gave best results was: $150 \mathrm{meq} / 100 \mathrm{~g}$ of dry clay, for the sample Bofe; $75 \mathrm{meq} / 100 \mathrm{~g}$ of dry clay, for the sample Chocolate; and $100 \mathrm{meq} / 100 \mathrm{~g}$ of dry clay, for the sample Verde-lodo.
Comparing the results presented in the Table 4 with the Petrobras specifications ${ }^{20}$, it was observed that: i) the dispersions with Bofe presented values of AV lower than the minimum $(15 \mathrm{cP})$. For the Chocolate and Verde-lodo samples AV were greater than $15 \mathrm{cP}$, except for Chocolate treated with $50 \mathrm{meq} / 100 \mathrm{~g}$ of dry clay and Verde-lodo treated with 50 and $75 \mathrm{meq} / 100 \mathrm{~g}$ of dry clay; ii) for PV, only the dispersions with Bofe clay, treated with all different proportions of $\mathrm{Na}_{2} \mathrm{CO}_{3}$, and Verde-lodo, treated with $50 \mathrm{meq} / 100 \mathrm{~g}$ of dry clay, presented values in agreement with the specifications, however very close to the minimum value $(4.0 \mathrm{cP})$; and iii) among the studied clays, only Chocolate, treated with all proportions of $\mathrm{Na}_{2} \mathrm{CO}_{3}$, and Bofe, treated with 150 and $175 \mathrm{meq} / 100 \mathrm{~g}$ of dry clay, presented values of WL below the maximum $(18.0 \mathrm{~mL})$, according to Petrobras specifications ${ }^{20}$. The $\mathrm{pH}$ values were close to the maximum value (10.0).

For industrialized clays the apparent viscosity changed from $8.3 \mathrm{cP}$ for the sample Brasgel to $16.1 \mathrm{cP}$ for the sample Brasgel PA. For the plastic viscosity the values change from $4.0 \mathrm{cP}$, for Brasgel PA to $5.0 \mathrm{cP}$, for Brasgel. The water loss changes from $20.5 \mathrm{~mL}$, for the samples Dolomil and Brasgel, to $16.3 \mathrm{~mL}$, for the sample Brasgel PA. The 
Table 4. Rheological properties of the suspensions prepared with the natural clays activated with $\mathrm{Na}_{2} \mathrm{CO}_{3}$ and of the suspensions prepared with the industrialized clays.

\begin{tabular}{cccccc}
\hline $\begin{array}{c}\text { Natural } \\
\text { samples }\end{array}$ & $\begin{array}{c}\text { Amount of } \mathrm{Na}_{2} \mathrm{CO}_{3} \\
\text { (meq/100g of dry clay) }\end{array}$ & $\mathrm{AV}(\mathrm{cP})$ & $\begin{array}{c}\text { Properties rheological } \\
\mathrm{PV}(\mathrm{cP})\end{array}$ & WL (mL) & $\mathrm{pH}$ \\
\hline Bofe & 75 & 7.1 & 4.3 & 18.8 & 9.9 \\
& 100 & 8.1 & 4.5 & 18.5 & 10.0 \\
& 125 & 10.0 & 4.0 & 18.5 & 10.0 \\
Chocolate & 150 & 12.5 & 4.8 & 17.7 & 10.0 \\
& 175 & 8.3 & 4.3 & 17.8 & 10.3 \\
& 50 & 13.6 & 3.8 & 16.5 & 9.5 \\
& 75 & 18.5 & 3.8 & 16.0 & 9.9 \\
Verde-lodo & 100 & 19.6 & 3.0 & 15.3 & 10.0 \\
& 125 & 18.8 & 2.3 & 15.8 & 10.0 \\
& 150 & 21.5 & 1.3 & 16.5 & 10.0 \\
& 50 & 9.5 & 4.0 & 21.8 & 10.0 \\
& 75 & 12.9 & 2.0 & 22.5 & 10.1 \\
& 100 & 16.9 & 1.5 & 22.0 & 10.2 \\
& 125 & 18.9 & 1.3 & 23.5 & 10.2 \\
& 150 & 20.4 & 1.0 & 23.8 & 10.0 \\
& & 11.8 & 4.3 & 20.5 & 9.9 \\
& Dolomil & 8.3 & 5.0 & 20.5 & 9.8 \\
& Brasgel & 16.1 & 4.0 & 16.3 & 9.9 \\
Brasgel PA & $\geq 15.0$ & $\geq 4.0$ & $\leq 18.0$ & $\leq 10.0$ \\
\hline
\end{tabular}

values of $\mathrm{pH}$ were close to 9.8 , for all the samples. Comparing these results with the specification ${ }^{20}$ for water based drilling fluids, it was observed that the values of AV presented by the suspensions prepared with the industrialized clays were inferior to the Petrobras specifications $(15 \mathrm{cP})^{20}$, except for the suspensions prepared with the sample Brasgel $P A$ that presented $\mathrm{AV}$ equal to $16,1 \mathrm{cP}$. The values obtained to $\mathrm{PV}$, are in agreement with the specifications, however very close of the minimum value $(4.0 \mathrm{cP})$; except for the sample Brasgel (5.0 cP). For WL, only the suspensions prepared with the sample Brasgel PA presented values below the maximum $(18.0 \mathrm{~mL})$. In relation to the $\mathrm{pH}$ values, all the samples presented results close to the maximum value (10.0).

\section{Discussion}

The water content of the samples is very low when compared with the Petrobras specifications (maximum 14\%) $)^{20}$ and can cause hydration problems if the clays is dry in high temperatures (above $60^{\circ} \mathrm{C}$ ). According to Souza Santos ${ }^{24}$, the hydration of the bentonite could be related with the presence of the potassium in its structure. During the dry process, when the interlayer water is excluded, the clays containing potassium can acquire a crystalline structure similar to muscovite mica. This modification hinders the water penetration between the layers. Consequent suspension of the clay in water causes small values of apparent and plastic viscosities. Among the studied clays, only the Verde-lodo sample presented a high content of $\mathrm{K}_{2} \mathrm{O}(1.99 \%)$, which can affect the rheologic properties. The amount of $\mathrm{K}_{2} \mathrm{O}$ in this sample is several times superior than when it was discovery, according to the Souza Santos ${ }^{6}$ results. The calcium, magnesium and sodium oxides of the natural clays also differ from the results presented by Souza Santos 30 years ago, and are inferior when compared with today results. The amounts of $\mathrm{Na}_{2} \mathrm{O}$ and loss on ignition were superior. Also it is important to say the amount $\mathrm{MgO}$ decrease from $3.5 \%$ to traces.

The thermodifferential curves and X-ray diffraction of the natural (Bofe, Verde-lodo and Chocolate) and industrialized clays confirm that these sample are predominantly composed of clay minerals of the group of the smectite, probably montmorillonites or members of the series nontronite-beidellite. All the samples contained quartz in its composition. The sample Verde-lodo contained illite and kaolinite. The presence of these clay minerals can affect the process of sodium transformation of bentonites, and consequently influence its rheological behavior. The presence of clay minerals montmorillonites in all the samples and illite and kaolinite in the sample Verde-lodo was confirmed by the electron micrographs. The mineralogical composition of the studied clays is similar to the clays studied by Souza Santos $^{6} 30$ years ago.

The natural clays, after treated with a $\mathrm{Na}_{2} \mathrm{CO}_{3}$ solution, can be transformed into sodium form, with rheological properties that do not satisfy the specifications of Petrobras ${ }^{20}$, to 
be used as water based drilling fluids. The reasons for this are probably due to the presence of calcium and magnesium, as bicarbonates, in the suspensions. The calcium and magnesium bicarbonates present high solubility and, when in solution, they are dissociated liberating the cations calcium and magnesium and can occupy the sodium positions in the structure of the clay, with reversible cation exchange. Although the mineralogical compositions of the clays are similar to the ones tested, the rheological properties showed that the clays do not present the same values of apparent and plastic viscosities. In some samples the presence of other minerals and/or non-montmorillonite clay minerals, probably contributed to its behavior with flocculated structure and gel formation of the suspensions.

Among the industrialized clays, only the sample Brasgel $P A$ presented rheological properties in agreement with the Petrobras specifications ${ }^{20}$.

\section{Conclusions}

The study of the physical, mineralogical and rheological properties of three samples of clays natural bentonites and three industrialized ones from Boa Vista, Brazil, led to the following conclusions:

- the physical properties presented by the samples are in agreement with the specifications of Petrobras ${ }^{20}$;

- the clay samples are composed of clay minerals from the smectite group, probably, montmorillonite or members of the series nontronite-beidellite. Also other minerals such as quartz and other clay minerals such as kaolinite and illite are included in the sample Verdelodo;

- the natural clays, when treated with $\mathrm{Na}_{2} \mathrm{CO}_{3}$ solution can be transformed into sodium form. However the rheological properties do not satisfy the Petrobras specifications;

- among the industrialized clays, only Brasgel PA presented rheological properties fit to be used as a component of water based drilling fluids;

- after four decades of exploitation, the bentonite from Boa Vista presents mineralogical composition similar to the one from the beginning of industrialization but its rheological properties became so different and the results show a drop in the quality of these clays.

\section{Acknowledgment}

The authors thank to the National Agency of Petroleum - ANP, FINEP, MCT, CNPq/CTPETRO and the CNPq's 'DCR' program for the financial support for the development of this work.

\section{References}

1. Darley, H.C.H.; Gray, G.R. Composition and Properties of Drilling and Completion Fluids, Gulf Publishing Company, Houston, p. 1-2, 553, 1988.

2. Murray, H.H. Applied Clay Science, v. 17, p. 207-221, 2000.

3. Nakaishi, K., Applied Clay Science, v. 12, p. 377-386, 1997.

4. Luckham P. F.; Rossi, S. Advances in Colloid and Interface Science, v. 82, p. 43-92, 1999.

5. Trindade, M.H.A. Bentonite. www.dnpm.org.br, 20 de setembro. 2001.

6. Souza Santos, P. Estudo Tecnológico de Argilas Montmoriloníticas do Distrito de Boa Vista, Município de Campina Grande, Paraíba, Tese de Cátedra, Universidade de São Paulo, Brasil, 1968.

7. Zandonadi, A.R.; Souza Santos, P.; Lourenço, P.O.B. Cerâmica, v. 16, p. 263, 1970.

8. Kiminami, R.H.G.A.; Ferreira, H.C. Cerâmica, v. 26, p. 307-312, 1980

9. Kiminami, R.H.G.A.; Ferreira, H.C. Cerâmica, v. 27, p. 21-36, 1981.

10. Kiminami, R.H.G.A.; Ferreira, H.C. Cerâmica, v. 27, p. 225-244, 1981.

11. Barbosa, M.L. Estudo de Algumas Propriedades Reológicas de Argilas Esmectíticas da Localidade de Bravo, Distrito de Boa Vista, Campina Grande, Paraíba, Após Cura em Câmara Climatizada, Dissertação de Mestrado, DEQ/UFPB, Campina Grande, PB, 1985.

12. Queiroz, M.F.V. Influência do Tratamento de Cura em Câmara Úmida e Climatizada nas Propriedades Reológicas e nos Teores de Carbonatos e Bicarbonatos das Argilas Esmectíticas de Boa Vista, Município de Campina Grande-PB, Dissertação de Mestrado-DEQ/ UFPB, Campina Grande, PB, 1985.

13. Ramos, R.R. Estudo de Algumas Propriedades Reológicas e Teores de Carbonatos e Bicarbonatos Após Cura em Câmara Úmida e Autoclave de Três Argilas Esmectíticas Tratadas com Carbonato de Sódio da Localidade de Bravo, Distrito de Boa Vista, Município de Campina Grande-PB, Dissertação de Mestrado, DEQ/UFPB, Campina Grande, PB, 1985.

14. Lira, H.L. Modificações de Propriedades Reológicas de Esmectíticas Sódicas por Tratamento Térmico, Dissertação de Mestrado - DEQ/UFPB, Campina Grande, PB, 1988.

15. Valenzuela Díaz, F.R. Estudos, em Escala de Laboratório, Visando Corrigir a Viscosidade Plástica Dilatante de Esmectita de Cor Verde-lodo, de Lages, Distrito de Boa Vista, Campina Grande, Paraíba, Dissertação de Mestrado, Universidade de São Paulo, Brasil, 1983.

16. Valenzuela Díaz, F.R.; Souza Santos, P.; Ferreira, H.C. Cerâmica, v. 32, p. 319, 1986. 
17. Gopinath, T.R.; Schuster, H.D.; Schuckmann, W.K. Revista Brasileira de Geociências, v. 11, p. 185-192, 1981.

18. Gopinath, T.R.; Schuster, H.D.; Schuckmann, W.K. Revista Brasileira de Geociências v. 18, p. 345-352, 1988.

19. Caenn, R.; Chillingar, G.V. Journal of Petroleum Science and Engineering, v. 14, p. 221-230, 1996.

20. Petrobras. Ensaio de Viscosificante para Fluido de Perfuração Base de Água na Exploração e Produção de Petróleo, Método, N-2605, Rio de Janeiro, Brasil, 1998.

21. Ferreira, H.C.; Chen, T.; Zandonadi, A.R.; Souza Santos, P. Cerâmica, v. 18, p. 333-326, 1972.
22. Anônimo. Métodos para Análise Química. Laboratório de Análises Minerais, Centro de Ciências e Tecnologia, Universidade Federal da Paraíba, Brasil, 2000.

23. Petrobras. Viscosificante para Fluido de Perfuração Base de Água na Exploração e Produção de Petróleo, Especificação, N-2604. Rio de Janeiro, Brasil, 1998.

24. Souza Santos, P., Ciência e Tecnologia de Argilas, Editora Edgard Blücher Ltda., SP, Brasil, p. 310-312, 1989.

25. Mendioroz, S.; Pajares, J.A.; Brito, I.; Pesquera, C.; Gonzalez, F., Blanco, C. Langmuir, v. 3, p. 676-681, 1987.

26. Srasra, E., Gergaya, F., Fripiat, J.J. Clays and Clay Minerals, v. 42, n. 3, p. 237-241, 1994. 
